\title{
Mediation as an alternative solution to medical malpractice court claims
}

\author{
N Claassen, BCom, LLB, LLM \\ Neels Claassen is retired judge in the High Court of South Africa, South Gauteng, Johannesburg and a retired member of the Alternative Dispute \\ Resolution Association of South Africa and the South African Association of Arbitrators.
}

Corresponding author: N Claassen (neelsclaassen15@gmail.com)

\begin{abstract}
Is there a crisis in the healthcare industry? Most certainly there is. Dr Motsoaledi, Minister of Health, publicly acknowledged the existence of such a crisis at a Medico-Legal Summit held at his initiative in Pretoria on 9 and 10 March 2015 at St Georges Hotel. ${ }^{[1]}$ Currently, as recently confirmed by the MEC for Health, Ms Mahlangu, there are about 2000 pending court cases against the Gauteng Provincial Health Department, the total quantum being claimed amounting to approximately ZAR 3.5 billion. During $2013 / 2014$ this department spent about ZAR 256 million on legal costs payable to claimants' attorneys. No budget for these expenses exists, resulting in payment being made from funds designated for the acquisition of medical equipment and other purposes. ${ }^{[1]}$ This undermines the department's ability to renew old equipment and upgrade to more modern equipment, resulting in even further claims. More claims are therefore to be expected. The Medical Protection Society also confirmed an increase in medical malpractice claims against their members of nearly $550 \%$ compared to 10 years ago. The quantum of claims that exceeded ZAR 5 million per claim, also increased by $900 \%$. ${ }^{[2,3]}$ The ripple effect of these increases in medico-legal claims causes insurance premiums for healthcare professionals to become exorbitantly expensive, resulting in some practitioners leaving the medical profession. Practitioners also act more defensively in applying their trade, resulting in additional and sometimes unnecessary tests that increase the costs of medical care and often cause further grounds for the institution of claims.
\end{abstract}

S Afr J BL 2016:9(1):7-10. DOI:10.7196.SAJBL.469

What motivates patients to institute court claims against healthcare professionals?

- The desire for monetary compensation: Parents claiming on behalf of injured children; dependents claiming for loss of support from a deceased; claims in respect of minors only prescribe after they reach 18 years of age resulting in forced settlements for lack of being able to defend the claim due to the absence of medical records and the relevant medical personnel associated with the event which occurred so long ago.

- Touting and advertising by lawyers: Touting is illegal but advertising is legal. Hospitals should more readily enforce their reserved rights of admission to remove persons caught touting for work from patients.

- Claiming on a contingency fee basis: No risk involved for the claimant, as the attorney is paid nothing if the claim fails but receives $25 \%$ of any amount successfully recovered.

- Lack of proper doctor/patient communication undermining 'informed consent': Proper explanatory communications with patients are important, both pre- and post-treatment.

- Deterioration of service by overburdened and understaffed medical personnel and equipment causes unnecessary adverse outcomes, giving rise to claims.

- Criminal conduct: It has been reported that healthcare staff unlawfully sell the hospital records to attorneys leaving the hospital defenceless. If attorneys are found to be in possession of original hospital records, it should be reported to the police for investigation. ${ }^{[1]}$

- Advent of constitutional protections: Section 10 (right to human dignity); section 11 (right to life); section 12(2) (right to bodily and psychological integrity); section 27 (right to healthcare services, ability to support dependents, right not to be refused emergency medical treatment); section 28 (children rights to basic healthcare services, protection from maltreatment, neglect, abuse or degradation, entitlement to legal representation in civil proceedings); section 34 (everyone has the right to go to court or other tribunal or forum). ${ }^{[4]}$

- Consumer Protection Act 68 of 2008 making patients aware of their rights and limiting the protective effect of exculpatory clauses: Section 22 (right to information in plain language); section 48 (right to fair, reasonable and just contract terms); section 49 (right to proper notice of certain terms and conditions); section 51 (prohibited terms and conditions); section 54 (right to quality service); section 58 (warning concerning nature of risks); section 61 (faultless liability for damage caused by goods and services). ${ }^{[5]}$

In Afrox Healthcare Bpk v, Strydom 2002 (6) SA 21 (SCA), ${ }^{[6]}$ a case decided PRIOR to the promulgation of the Consumer Protection Act, the Supreme Court of Appeal in Bloemfontein enforced an exemption clause in the admission document of the hospital that absolved: '... the hospital and/or its employees and/or agents from all liability and indemnified them from any claim instituted by any person (including a dependant of the patient) for damages or loss of whatever nature (including consequential damages or special damages of any nature) flowing directly or indirectly from any injury (including fatal injury) suffered by or damage caused to the patient or any illness (including terminal illness) contracted by the patient whatever the cause/causes are, except only with the exclusion of intentional omission by the hospital, its employees or agents.' 
The negligence of a nurse (tying bandages too tightly which cut the blood supply to the wound) caused complications and the claimant suffered damages, but the court ruled that such negligence was excluded by the exemption clause and held the hospital not liable for the claimed damages. It is doubtful whether this conclusion would in future be upheld in light of the clauses referred to above in the Consumer Protection Act. In particular, Regulation 44(1) introduced by the Minister responsible for consumer protection matters, provides that a consumer agreement is presumed to be unfair if it has the purpose or effect of 'excluding or limiting the liability of the supplier for death or personal injury caused to the consumer through an act or omission of that supplier! ${ }^{[6]}$

In Britain the Unfair Terms Act of 1977, prohibits the exclusion of liability for negligence, including ordinary negligence, leading to bodily injuries or death. In terms of section 2(2)(a) of our Consumer Protection Act, courts in South Africa (SA) are permitted to take cognisance of 'appropriate foreign and international law' when interpreting the Act and may well in future lean towards greater protection of patients' rights as in the UK. ${ }^{[5,7]}$ This provision is also in line with section 39(1) and (2) of our Constitution, which enjoins courts to develop the common law in the spirit, purport, and objects of the Bill of Rights and, in doing so, it must take cognisance of international law and may consider foreign law. ${ }^{[4]}$

\section{2 main disadvantages of litigation}

- It has become too costly; however, it would seem the same holds true for arbitration. Litigants are enticed by the promise inherent in 'contingency fee' based cases that their attorney will not charge if the case is lost but will charge $25 \%$ of any amount successfully recovered. They tend to forget, however, that if the case is lost, the winning parties' costs will be for their account. Also, taking $25 \%$ of any damages recovered can be substantial depending on the amount so awarded. ${ }^{[1]}$

- It is too time consuming: It takes years to come to trial and then there may be interim procedures, postponements and/or further appeal processes extending the final conclusion of the matter even further. The economy of settling now for ZAR 1000 instead of 4 years down the line is not always adequately explained.

- There is usually a winner and a loser and sometimes both are dissatisfied with the outcome!

- Lawyers prevent opposing parties from communicating with one another and so prevent any early amicable settlement between them. 'Don't speak to me, speak to my lawyer'!

- Adverse publicity and cross-examination can ruin a successful professional career, even in cases where the claim is completely unmeritorious. Adverse publicity and cross-examination can also undermine a patient's dignity even in successful claims.

- Not all adverse outcomes or mistakes or errors constitute negligence justifying the institution of a claim. ${ }^{[8]}$

- Most claims are settled at the doors of court after the parties had already suffered much trauma and incurred substantial legal costs.

- Often the root of the complaint is never disclosed or dealt with in the proceedings because of the absence of evidence about the true cause of the patient's complaint.

- Many claims are instituted long after the event that gave rise to the alleged damages, this seriously hampers the proper investigation and ventilation of all relevant facts to enable a just verdict to be reached.
- The presiding officers in courts are judges and magistrates who are not necessarily au fait with complex medical procedures and complications, sometimes resulting in unjust decisions.

- Litigation seldom, if ever, results in reconciliation of the opposing parties.

- Court decisions are sometimes based on legal technicalities (exceptions, prescription, lack of compliance with notice periods, etc.) that are far removed from the parties' needs, leaving the matter unresolved and both parties dissatisfied.

\section{Mediation}

During December 2014 the court-annexed mediation in certain Magistrates Courts in Gauteng and North West, was inaugurated. ${ }^{[9]}$ Rule 73 of the Magistrates' Court Rules defines mediation as the 'process by which a mediator assists the parties in actual or potential litigation to resolve the dispute between them by facilitating discussions between the parties, assisting them in identifying issues, clarifying priorities, exploring areas of compromise and generating options in an attempt to resolve the dispute'. Rule 71 (b), (c), (d) and (f) declares that the main purpose of mediation is to 'promote restorative justice ... preserve relationships between litigants or potential litigants which may become strained or destroyed by the adversarial nature of litigation; facilitate an expeditious and cost-effective resolution of a dispute ... provide litigants ... with solutions ... which are beyond the scope and powers of judicial officers'.

The success rate of mediations is estimated at between $80 \%$ and $90 \%$. In the year 2000, Singapore boasted a success rate of $93 \%$ out of 3943 cases. ${ }^{[10]}$ Mediation is suitable for the resolution of multiple disputes between multiple parties, such as between individuals on the one hand and companies, municipalities and even government departments on the other. ${ }^{[1]}$ It equalises power imbalances in the process.

In Hong Kong legal practitioners are liable to be disbarred if they fail to first advise their clients on the benefits of mediation before resorting to court litigation. In Britain it was decided in Halsey $v$. Milton Keynes NHS Trust [2004] EWCA Civ 576 that 'all members of the legal profession who conduct litigation should now routinely consider with their clients whether their disputes are suitable for ADR.' (Alternative Dispute Resolution, such as refereeing, mediation or arbitration.) ${ }^{[12]}$

Before any mediation commences, the mediator and the parties normally sign a mediation agreement wherein all the attributes of mediation are contractually secured. ${ }^{[13]}$

The Minister of Justice has been quoted as saying that he intends to submit to cabinet a policy framework to facilitate the diversion of all claims against the state, first to mediation. ${ }^{[14]}$ The Ministry of Justice retains a list of qualified mediators.

\section{The attributes and benefits of mediation}

- Mediation is far less costly than litigation or arbitration. According to the Government Gazette mediation tariffs have been set, inter alia determining that a level 1 mediator may charge ZAR 4500 and a level 2 mediator ZAR 6000 as a maximum fee per day shared equally by both parties. ${ }^{[15]}$

- Mediation is far less time consuming than litigation or arbitration. It has been estimated that the largest portion of mediations are completed in less than a day. Mediating parties are also not 
subject to waiting time for trial dates, as in the courts. It is only the mediator and the parties who have to coordinate their diaries for a suitable date.

- Mediation is a voluntary and not a compulsory process and under no circumstances does it deny a party's right to withdraw and enforce his right to litigate in court. If any party feels aggrieved by the mediation process, withdrawal at any stage is permissible. In such event, the mediator would usually ask for a private session with the aggrieved party to enquire the reason for his or her dissatisfaction in order to have an opportunity to remove any misunderstanding and hopefully convince that party to continue with the process. Where the mediator is of the view that the aggrieved party is unreasonable in his refusal to continue with the mediation, he will record such fact and a subsequent court hearing the dispute may issue a punitive costs order against such party. Although it is generally not a compulsory process, certain legislation obliges disputing parties to submit their disputes to mediation first before instituting litigation.

- Mediation is an informal process. The formal laws of evidence and the rules of court do not bind the parties. Knowledge of court procedures is, therefore, not a prerequisite for parties to engage in mediation successfully.

- Mediation is without prejudice to either party's rights. This allows parties to speak freely without fear of their rights being adversely affected. Such freedom often leads to the parties getting to grips with the real problem. If, however, the mediation fails, then neither party is allowed to refer to anything said or admitted during the mediation during any later court proceedings.

- Mediation is a private and confidential affair where no adverse publicity will influence the parties to withhold the truth. It is a safe place to speak the unadulterated truth! It is also permissible to have your own attorney present throughout the mediation process. Experience has shown that it is sometimes beneficial to have the parties' attorneys present. It makes their clients feel safe and comfortable and undermines any fear they may have that they will be prejudiced.

- Mediation is client based, i.e. the interests or needs and not the rights of each party are paramount. It is not rights based, as is the case in litigation or arbitration. The skilled mediator guides the parties to a mutual solution satisfactory to them irrespective of their legal rights. Thus, they arrive at a solution designed by their own needs leaving two winners instead of a loser and a winner. In arriving at a solution, the parties are not limited to their legal remedies. Often, a mere apology suffices to bring healing to broken relationships. It would be wise to remember, 'having your day in court' does not always result in 'having your say in court'.

- Mediation called for at the earliest moment possible allows the parties to face one another after the event sooner than in litigation. At such early stage, attitudes have not yet hardened and the relevant documentation and personnel that can shed light on the causes of the problem are usually still available. No waiting time for trial dates is required and the problem can be resolved while everything is still fresh in the memory of the respective parties.

- The mediator facilitates any lack of understanding or any miscommunication existing between the parties in language devoid of legal formalism or scientific technicalities. Where the problem is, however, technical or scientific in nature, the mediator will be in a position to guide the parties to appoint a single independent expert to look at the problem and give a neutral view or explanation. Both parties are encouraged to agree in advance to accept the independent expert's conclusion and to share equally his or her fees. Usually this procedure will resolve the problem, resulting in a far more cost-effective resolution of the dispute than a procedure where each party employs his or her own expert.

- Another benefit of mediation is that it engenders equality between the parties and removes any imbalance in power between the 'stronger' professional and the 'weaker' lay patient. This balance occurs during private sessions that the mediator conducts with each party in the absence of the other, where the weaker party is free to speak without reservation. This freedom usually discloses the real nature of the dispute and the real needs of the party.

- Mediation allows the parties greater control over the process in comparison to litigation where their legal representatives are in control. The process of mediation removes the disadvantages of the adversarial nature of litigation. The adversarial process produces surprises that are often devastating to the parties. Cases are often decided on legal principles far removed from the parties' interests, e.g. a case may be decided on depending on whom the onus of proof rests, a concept far removed from the parties' interests and real needs.

- A mediator does not supply the parties with a verdict. Nor does the mediator judge the credibility of the parties and/or their witnesses. A mediator does not cross-examine anyone as is done in court or arbitration proceedings. The bona fides of each party or person are accepted without question, and this removes the threatening atmosphere that is so often prevalent in court proceedings. It is a safer place to protect one's dignity and reputation.

\section{How is mediation initiated and implemented?}

Once the parties have agreed to submit their dispute to mediation, a mediator is appointed suitable to both parties. Parties may approach any person known to be a qualified mediator or they may approach the Clerk of the Magistrates' Courts where court annexed mediation is practised or they may approach the Ministry of Justice for referral to a mediator if none is known by the parties.

A mediation agreement is signed which also reflects the mediator's fees as well as all the attributes of the process referred to above. The mediation can then take place at any convenient place agreed upon by the parties, usually at no cost to either party.

The process of mediation usually commences with a joint session where each party is given an opportunity to state his or her case to the mediator. In so doing, the mediator obtains, in advance, undertakings from the parties to avoid all derogatory language in stating their case. If they disobey, the mediator reminds them of their undertaking and so maintains peace and a comfortable atmosphere.

After this session, the mediator explains that each party is now afforded an opportunity to discuss in private with the mediator his or her grievances. During this session the mediator undertakes not to disclose anything said in confidence to him to the other party unless the party in session authorises the mediator to do so. If either party in private session authorises the mediator to disclose to the other party certain confidential information, the mediator normally writes it down and checks with the party whether the information to be disclosed has been correctly recorded. It is then within the discretion of the mediator to decide when he or she regards it as profitable or 
wise to make such disclosure to the other party. The mediator then meets privately with the other party under the same conditions.

After the private sessions, the mediator calls both parties into open session if it is deemed advisable to do so within his discretion, alternatively he can commence with another round of private sessions to test and see whether the parties have closed the gap in their differences. This process is repeated until the parties reach a solution satisfactory to both.

Once the parties arrive at an agreement, the mediator assists them in recording the settlement in writing whereafter each party signs the agreement. The agreement can be made an order of court. This has the benefit that if either party breaches the terms of the agreement, the other party can enforce the agreement by execution through the sheriff of the court. If it was not made an order of court, the agreement can be enforced through litigation. It is always easier to enforce an agreement arrived at by way of settling a dispute than having to prove your rights without such a settlement.

\section{Conclusion}

It would be to the benefit of all state hospitals against which malpractice claims have been instituted, to attempt agreeing with the claimants and/or their legal representatives to refer such court cases for resolution by mediation. Such requests for mediation must preferably be in writing. In case the claimants or their legal representatives refuse unreasonably to agree to mediation, such refusal could be used to obtain an adverse costs order against them at the end of the court case, thus saving the state having to pay the inordinate amount of legal costs, as in the past.

\section{References}

1. Dhai A. Medico-legal litigation: Balancing spiralling costs with fair compensation. S Afr J BL 2015;8(1):2-3. DOI:10.7196/SAJBL.407

2. Botes M. Mediation: A perfect solution to healthcare disputes. De Rebus 2015;28(4):67.

3. Pepper MS, Slabbert MN. Is South Africa on the verge of a medical malpractice litigation storm? S Afr J BL 2011;4(1):29-35.

4. Republic of South Africa. Constitution of the Republic of South Africa No. 108. Bill of Rights:7-39. Government Gazette, 1996.

5. Republic of South Africa. Consumer Protection Act 68. Government Gazette 2008

6. Afrox Healthcare Bpk v. Strydom 2002 (6) SA 21 (SCA) the Supreme Court of Appeal in Bloemfontein.

7. United Kingdom Legislation. Unfair Terms Act. London: United Kingdom Legislation, 1977. http://www.legislation.gov.uk/ukpga/1977/50?view=plain (accessed 20 September 2015).

8. Buthelezi v. Ndaba 2013 SA 437 (SCA).

9. Republic of South Africa. Rules Board for Courts of Law Act (107/1985): Districts and subdistricts for implementation of Rules of Medication (GN 855 GG 38164/31 10-2014). Pretoria: Government Gazette, 2014

10. Van der Merwe BC. Court annexed mediation: Should it be embraced by the legal profession. De Rebus 2015;24(4):66.

11. Republic of South Africa. Rules Board for Court of Law (83/1985). Pretoria: Government Gazette, 2014

12. Halsey v. Milton Keynes NHS Trust [2004] EWCA Civ 576

13. Republic of South Africa. Rules Board for Courts of Law Act. Form MED-6 of Annexure 3. Pretoria: Government Gazette, 2014

14. Manyathi-Jele N. Court annexed mediation officially launched. De Rebus 2015;11(4): 57.

15. Republic of South Africa. Rules Board for Courts of Law Act (107.1985): Fees payable to mediators, qualification standards and levels of mediators (GN 854 GG 38163/31-10-2014). Pretoria: Government Gazette, 2014. 